\title{
Impact of Training and Development of Employees on Employee Performance through Job Satisfaction: A Study of Telecom Sector of Pakistan
}

\author{
Afaq Ahmed Khan (Corresponding author) \\ Lecturer, Government College of Management Sciences, Abbottabad, Pakistan \\ E-mail: afaq.a47@gmail.com.
}

\begin{abstract}
Sardar Osama Bin Haseeb Abbasi
Student at Government College of Management Sciences, Abbottabad, Pakistan

E-mail: osamaabbasi23@yahoo.com.
\end{abstract}

\section{Raja Muhammad Waseem}

Student at Government College of Management Sciences, Abbottabad, Pakistan E-mail: pisces_2003_121@ hotmail.com.

\section{Mohsin Ayaz}

Student at Government College of Management Sciences, Abbottabad, Pakistan E-mail: mohsinayaz80@gmail.com.

\section{Moazzam Ijaz}

Student at Government College of Management Sciences, Abbottabad, Pakistan E-mail: mzeeijaz@gmail.com.

Received: February 14, 2016 doi:10.5296/bms.v7i1.9024
Accepted: March 3, 2016 Published: April 22, 2016

URL: http://dx.doi.org/10.5296/bms.v7i1.9024 


\section{Abstract}

Training and development of employees and job satisfaction of employees are two crucial components for the performance of employee. In this study the influence of training and development on employee performance through job satisfaction is studied. 115 questionnaires were distributed among employees i.e. executives and managers of Telecom companies in Abbottabad, Haripur and Mansehra of which 105 were returned. Convenience sampling technique was used for data collection. The response rate was $91 \%$. The finding of our study showed positive impact of training and development and job satisfaction with employee performance. Training and development will lead to higher job satisfaction level in employees and they will fulfill their duties with a great deal of responsibility with best performance.

Keywords: Training and development, Job satisfaction, Employee performance 


\section{Introduction}

Employee performance is commonly researched topic by researchers. Employees are most precious asset for any company as they can build up or destroy reputation of company and they can effect profitability (Elnaga \& Imran, 2013). Employee performance is influenced by many factors like company's overall policies, working conditions, training and development of employees, relations between employee and employer etc. (Aktar et al., 2012). Employee performance can be enhanced by various ways. Employee performance plays a crucial role for any organization or company, its positivity leads to success while if there its negativity may lead to failure. It is usually perceived that if employees are satisfied with their job or working conditions their performance will be much better than those employees who are not happy with their work. Employee performance can be measured by various ways like productivity, absenteeism and employee satisfaction (Osunde, 2015). Employee performance as in any other sector or organization is very important likewise in telecom sector. Employee performance is also a key ingredient for success. In telecom sector if employees will perform well, the customers will be satisfied and if customers will be satisfied overall performance of the company will be good and satisfactory.

There were 14000 land lines at the time when Pakistan got independence. Telephone and Telegraph Department (T\&T) came into existence when in 1962 Post Telegraph and Telephone were separated from each other, and on $15^{\text {th }}$ December 1990 the Telegraph and Telephone Department was transformed into Pakistan Telecommunication Corporation. Pakistan Telecommunication Authority (PTA), the National Telecommunication Corporation (NTC), Frequency Allocation Board (FAB) and Pakistan Telecommunication Company Limited (PTCL) were established by updating the supposed system on $1^{\text {st }}$ January 1996. The fixed line telecommunication sector was opened up in Pakistan, the monopoly of PTCL in telephony was finished when Deregulation Policy for Telecom Sector announced in 2003. The Government of Pakistan awarded two cellular Mobile Telephone Licenses to Paktel and Pak Com i.e. Instaphone and therefore cellular services started in 1990s. M/s Pakistan Mobile Communications Limited (PMCL) Mobilink was issued third cellular license in 1992 by the Ministry of Communication and it established Global System for Mobile Communication (GSM) network. In 2001 Pakistan Telecommunication Mobile Limited (Ufone) for provision of GSM service was issued fourth license by PTA. This step was taken to meet the increased demand for cellular phone. Warid and Telenor were awarded mobile licenses through open bidding against auction bidding price of US\$291 million each in the year 2004("Case study telecommunication Pakistan,"). Paktel was renamed to Zong in 2008 and Zong started its services. Telecom revenues reached to Rs.299.0 billion during Jul-Dec 2014-15, and due to this reason this sector became more eye-catching for further investment. 75.2 percent of population has now access to facilities so teledensity has improved. Socio-economic progress of the country will be promoted due to the introduction of $3 \mathrm{G} / 4 \mathrm{G}$ spectrum. An investment of US\$ 1790 million was brought by the auction of $3 \mathrm{G} / 4 \mathrm{G}$ spectrum. Contribution of 73.22 billion was made to the national exchequer in terms of taxes etc. by telecom sector during July-Dec, 2014-15. At the end of March, 2015 cellular mobile subscribers reached to 134.9 
million ("Pakistan economic survey," 2014-15).

This is the era of competition and cellular companies will have to be more creative in using human resource practices (Iun \& Huang, 2007). Telecom sector is most rapidly growing sector of Pakistan and this sector has seen many changes during past few years including changes for requirement of technology, coverage of network and escalating competition, so these changes resulted in requirement of well trained employees (Sultana et al., 2012). There is an intensifying competition among companies in telecom sector of Pakistan in the form of innovation, new technology and pricing etc., so mobile operator companies of Pakistan needs to prepare their employees for upcoming challenges and they should be ready to accept the changes and enhance their performance (Asim et al., 2012). Mobile and telecom technology are advancing rapidly, GSM and internet enabled tablets and mobile phone devices will be used (Imtiaz et al., 2015). The main purpose of training and development is to prepare employees to work in current environment to their best possible abilities and to develop them for upcoming challenges. Training and development programs create awareness among employees for using of new technology (Imran et al., 2014). Keeping all the above facts in mind it is quite clear that mobile operator companies will see fierce competition locally and globally in terms of pricing, usage of new technology and in terms of providing high quality of service. So in these circumstances employees should be trained and developed well enough to meet these challenges specifically training for using of new and sophisticated technology. Apart from training managers will have to prove that they care about their employees, so that employees also care about them and they will be satisfied which in result will enhance company's performance and a company will have edge over other companies.

This proposed study will be very useful for management of telecom and mobile companies. They will be able to conduct training and development programs which will satisfy the employees that their management is taking care of them and they will be happy and this satisfaction will lead to improved employees performance. And also they will be able to develop a team of employees which will perform quite well in changing environment, technology and intense competition.

\subsection{Research Objectives}

To determine the impact of training and development of employees on employee performance.

$>$ To investigate the relationship of job satisfaction mediated between training and development of employees and employee performance.

\section{Literature Review}

\subsection{Employee Performance}

Employee performance is based on individual factors, namely: abilities, knowledge, skills, experience, and personality (Vroom, 1964). It is up to employee that how he performs high in a job and high productivity and good results must be delivered by employee (Hunter \& 
Hunter, 1984). Employee satisfaction can be measured with help of factors like job satisfaction and absenteeism (Gibson, 1990). If the employees are performing well then the overall image of the company is boosted because employees perform good if they are satisfied with their work so they will not leave the company which shows their faith in the management that they are taking care of their employees, the employees leaving the company or firm don't have good opinion about management and they start to speak bad about that company as soon as they leave it, which leads to destruction of reputation and in this changing world reputation is everything. Regard less of what the work is, an individual performance shows the understanding and capability to accomplish the targets linked with correctness (Shanawany, 2001).

Job performance of an employee at place of work is also called as employee performance and it deals with the accomplishment of tasks which are given to workers by the top management (Khan \& Imtiaz). The idea of employee performance as dependent variable is broadly used in Organizational and industrial psychology (Kahya, 2009). Organizations should focus on the factors which improve the performance of employee as an employee performance is significant component of organization (Abbas \& Yaqoob, 2009).

Firm's crucial component is employee and their success and failure depends on performance of employee (Hameed \& Waheed, 2011). Performance can be defined as the fulfillment of particular task calculated against already known standards like that of accuracy, speed and cost and how accurately employees perform the task determines the good performance and also organizations have some expectations regarding performance of employees, when that level of expectation is meet by the employees they are called as good performers (Sultana et al., 2012). Practices of human resource management have been positively associated with development areas of an employee and employee performance and this fact is opened by previous studies (Hafeez \& Akbar, 2015). We can say that employee performance is composed by the behavior of the employee and outcomes which come when the tasks of job are completed by using specific abilities and these results are measured by various scales (Imran \& Tanveer, 2015).

\subsection{Training \& Development and Employee Performance}

Not everyone who joins the organization is fully aware or up to the job at the moment he joins the organization. As we know learning is continuous process so everyone has always a space for learning something new. So the employees who may be suitable for job but let's say they are bit older and they have been performing well in the organization, but what if at their time the technology used was not the same as its now?, they will face obviously problems in performing well, so the training and development programs help everyone to learn something new or improve current skills. The requirements of job can be meet by providing employees proper training (Dayal, 1970). Almost same point was discussed by (Arnoff, 1971) he mentioned that hurdles in adopting new technology or barriers which employees face in performance or productivity can be removed by conducting training sessions. Training and development play a crucial role in human resource management as it helps to groom and 
improve skills of employees which in turn increases employee performance (Guest, 1997). Improved employee performance is expected from training and development (Elangovan \& Karakowsky, 1999). Training is organized attempt of an employee to acquire efficient performance in single or multiple activities (K. Z. Ahmad \& Bakar, 2003). Employees should be fully involved in training programs and there must be a relation between employee and company(McConnell, 2004). Development is process of planning and preparing employees for the future jobs and upcoming problems (Kadiresan et al., 2015). In $21^{\text {st }}$ century main challenge for mangers of human resource will be training and development (Stavrou et al., 2004). Training \& Development is a process of increasing the performance of employee as well as their behavior is corrected (Naris \& Ukpere, 2009). Training and development helps businesses to adapt to new technology by increased efficiency of employees (Kennedy, 2009).

When it has been determined that out of all people working in organization which employees should be given training and which areas they need training only then the training can be launched properly (Kum \& Cowden, 2014). People working in an organization create workforce, and the work force should be skilled enough to perform in well interest of company. Training and development programs ensure that the work force is developed and skilled so that they can perform well (Bataineh, 2014).Training and development acts like the back bone to the health industry (Ahmad \& Din, 2009). Training and development programs always gives employees chance to learn something new. Training is full of learning and creativity so to stay ahead of competitors training is necessary (Niazi, 2011). Developing forward in tasks and enhancing skills of employees could be listed as expected outcomes of ideal training program (Chidambaram \& Ramachandran, 2012). Training and development helps in improving old skills and enhancing the current skills of employees (Kulkarni, 2013). Training and development programs should also be monitored by the organizations, as they are investing huge amounts on these programs they should monitor the performances of employees that whether these programs are making any changes in behaviors of employees or not. Besides monitoring following these programs is also main responsibility of organizations, they should make ensure that the training and development programs are followed by employees and they are responding to the efforts put by the organization to make changes in them. As Gamage and Imbulana (2013) have mentioned that highly skilled, motivated and boosted morale workforce will be created if the organizations conduct training and development programs and follow them. Training is used to get distinguish place among rivals in the competition (Jehanzeb \& Bashir, 2013). Training minimizes the difference between current performance of employees and the performance desired (Elnaga \& Imran, 2013). Human resource management's vital function is training and development and the employees who take part in these programs are highly functional and their performance has improved as compared to those who show no or less interest in training and development programs (Javaid et al., 2014). Employees who have not participated in training and development programs have done loss not to anyone but to themselves. They may not have participated due to various reasons like that of overconfidence that they have already those 
skills which will help them in future or they feel that they don't need to be trained again $n$ again because they may feel irritated, what so ever was the reason the ultimate loss will be of theirs because training and development programs would have improved their current skills and also they would have come to know about the knowledge of tackling with upcoming problems. Well trained and developed employees face less or no issues in performing tasks or jobs assigned to them by management as compare to employees who don't have sufficient training. Work practices are changing on continuous basis, so if the employees are not provided adequate knowledge and they don't get the chances of learning new things they may feel hurdles in skills to perform their job, the training process is a continuous process so that the employees may respond to changes happening around them in an efficient way (Imran \& Tanveer, 2015).

Management do not have surety that the money they are investing in training programs will benefit them so they are reluctant in investing, it may be because employee sees it as opportunity to groom his skills so that his market value increases and they may leave the firm due higher salary in other firm, so the investment made by firm in training turns out to be loss instead of profit (Cheramie et al., 2007). Managers have now recognized the importance of reducing the difference between current skills and the skills required to cope with changing technology so they are now investing in training and development programs (Mansour, 2013). The results of study which was conducted by Sultana et al., (2012) in telecom sector of Pakistan showed that there is positive impact of training on employee performance. Thus we hypothesis that:

H1: Training and development of employee has positive impact on employee performance.

\subsection{Job Satisfaction and Employee Performance}

Job satisfaction is feelings of a person which come positively when appraisal comes from person's job (Locke, 1976). Job satisfaction is perceived level to which the important job values are fulfilled by the one's job (Locke, 1976). How an individual thinks and feels about his job can be said as job satisfaction (Spector, 1997). The limit to which the expectations which are psychological and social and are met and satisfaction or dissatisfaction towards the job, is job satisfaction (Testa, 1999). Some defined job satisfaction in terms of liking the job (Ellickson \& Logsdon, 2002). Level of satisfaction will be low when the policies made by management are in conflict with the expectations of employees (Rothbard, 2005). There are some expectations of employees towards the company and their management that when they will make policies, there opinion will be included and such policies will be made which will be beneficial for employees, but when the policies made by company does not involves employees and is against the interest of employees the satisfaction level lowers. If there is conflict between employee and supervisor it will lead to dissatisfaction of employee.

Job satisfaction is effected by the relationship between employees and supervisor, salary and working conditions Mudor and Tooksoon (2011) while timings of working hours and the feeling that employee are not valued, causes dissatisfaction (Shaikh et al., 2012). The things 
which make an employee to stay in the job and makes employee happy are the factors of satisfaction in job (Saif et al., 2011). Job satisfaction is studied by many researchers as important variable due to its association with other outcomes of organization such as performance and turnover (Sušanj \& Jakopec, 2012). Employee satisfaction and expectation are changing along with the changing world (Uddin et al., 2012). If the employees are satisfied with their job in the company they will make efforts to bring some innovation and creativity by the good performance which will give company important breakthroughs in these changing market conditions (Achieng'Odembo, 2013). It should be recognized from employees point of view as well from organizations point of view that job satisfaction will lead to better performance as the interest of employee towards his job will be increased (Gupta, 2014). An individual's behavior while on job says a lot about satisfaction of employee (Masood et al., 2014). Job satisfaction is now mostly studied in management studies ,but it should be kept in mind factors effecting job satisfaction differ from employee to employee (Anjum, 2014) and this idea that employee satisfaction varies from person to person was also supported by (Kavita et al., 2012) in their study.

Job satisfaction has positive relation with the performance of employee as the worker is satisfied and more involved in job the performance automatically increases (Velnampy, 2008). Job satisfaction and performance are directly related to each other which means that if the satisfaction level is high the performance will be also good and vice versa (Pushpakumari, 2008). When the organization pays attention to the employees, listens to their problems and their grievances are heard properly the employees feel satisfied that their voice does matter and organization is there to help them. So the employees naturally tend to perform well and move towards the goals of organization and in this way they pay back to the organization. Employee performance increases with increased level of satisfaction. Job satisfaction is also due to the fact that employee is happy with his/her overall performance and feels that he/she is contributing in success of organization. Thus we hypothesis that:

H2: Job satisfaction has a positive influence on employee performance.

\subsection{Job Satisfaction as a Mediator}

Trained employees were more satisfied than the untrained employees (Abdulla et al., 2011). When the training and development programs are held each and every employee has a chance to improve his current skills and adopt new skills which might be needed in future. In training and development sessions employee can see where they are performing well and in which areas they are lacking behind or their performance is not satisfactory. So in this way the employees have perception that organization is helping them to increase their skills and they feel that if they will have some sort of issue regarding performance they, by participating in training and development programs can resolve those issues and in result they are satisfied that they are being valued by organization and organization is investing in them. These all factors leading to satisfaction result in highly improved employee performance. When the employees are well trained and they know that their organization is spending huge sum of money in training and development programs they in return want to give back to organization 


\section{Macrothink}

by showing them their improved performance. As the employees are satisfied with their job they don't feel any stress or burden, which are most common reasons for employee's bad performance, the employees are happy and it is common perception that happy employees are good performers. Thus we hypothesize:

H3: Job satisfaction mediates between T\&D and EP.

\subsection{Theoretical framework}

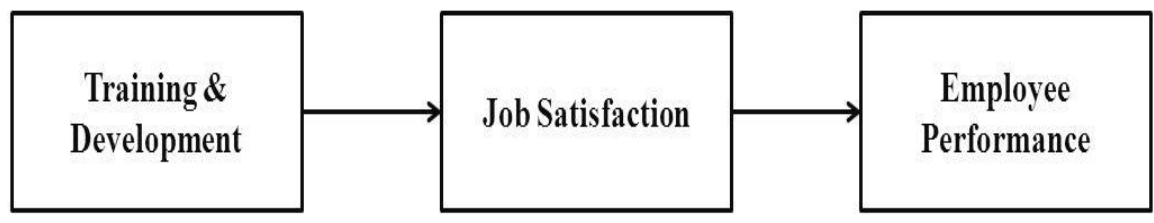

\section{Methodology}

\subsection{Sample and Data Collection}

110 questionnaires were distributed among the Managers and Customer Services Representatives in the telecom sector operating in Abbottabad, Haripur and Mansehra. 105 questionnaires were returned with complete information required. The response rate was agreeable. Convenience sampling technique was used for this study. The data was gathered by using self-administered questionnaire and the participation was voluntary.

\subsection{Measures and Scales}

Three variables were used in this study i.e. Training and development, employee performance and job satisfaction. Training and development is used as an independent variable while employee performance as a dependent variable and job satisfaction as Mediator. Equally 10 questions of training and development and employee performance were used. The questions were adopted from the study of (Masood, 2010). Job satisfaction had 7 questions which were adopted from the study of (Cook \& Heptworth, 1981). All variables were measured using a 5 -point likert scale in which 5 represented strongly agree to 1 which is strongly disagree.

\section{Results and Discussion}

Table 1. Demographics

\begin{tabular}{clcc}
\hline Descriptions & & Frequency & Percentage \\
\hline \multirow{2}{*}{ Gender } & Male & 98 & 93.3 \\
& Female & 07 & 6.7 \\
\hline \multirow{2}{*}{ Marital Status } & Single & 51 & 48.6 \\
& Married & 54 & 51.4 \\
\hline \multirow{5}{*}{ Age } & $20-25$ & 26 & 24.8 \\
& $26-30$ & 38 & 36.2 \\
& $31-35$ & 26 & 24.8 \\
& $36-40$ & 10 & 9.5 \\
& $40+$ & 05 & 4.8 \\
\hline
\end{tabular}




\begin{tabular}{|c|c|c|c|}
\hline \multirow{4}{*}{ Qualification } & Intermediate & 19 & 18.1 \\
\hline & Bachelors & 36 & 34.3 \\
\hline & Masters & 42 & 40.0 \\
\hline & MS/M.Phil. & 08 & 7.6 \\
\hline \multirow{7}{*}{ Employee of } & Ufone & 21 & 20.0 \\
\hline & Telenor & 13 & 12.4 \\
\hline & Warid & 14 & 13.3 \\
\hline & Mobilink & 17 & 16.2 \\
\hline & Zong & 10 & 9.5 \\
\hline & PTCL & 26 & 24.8 \\
\hline & wateen & 04 & 3.8 \\
\hline
\end{tabular}

Table 1 shows demographics for sample size $\mathrm{N}=105$ to observe the relative impact of variables amongst each other. Sample consists $93.3 \%$ of male and $6.7 \%$ of female population, including age groups categorized as 20-25 (24.8\%), 26-30 (36.2\%), 31-35 (24.8\%), 36-40 $(9.5 \%)$ and 40 and above $(4.8 \%)$.

Table 2. Reliability

\begin{tabular}{ccc}
\hline Variable & Cronbach'sAlpha & No of Items \\
\hline T\&D & .810 & 10 \\
EP & .734 & 10 \\
JS & .658 & 07 \\
\hline
\end{tabular}

Table 2 exhibits good level of reliability of scale items in terms of Cronbach's Alpha for Training and development ( $\alpha=81 \%)$, Employee Performance $(\alpha=73.4 \%)$ and Job Satisfaction $(\alpha=66 \%)$.

Table 3. Correlation

\begin{tabular}{|c|c|c|c|c|c|c|}
\hline Variable & & Mean & S.D & T\&D & EP & JS \\
\hline T\&D & $\begin{array}{l}\text { Pearson } \\
\text { correlation }\end{array}$ & 3.9705 & .57444 & 1 & & \\
\hline EP & $\begin{array}{l}\text { Pearson } \\
\text { correlation } \\
\text { Sig } \\
\end{array}$ & 3.9914 & .48637 & $\begin{array}{c}.718 * * \\
.000\end{array}$ & 1 & \\
\hline JS & $\begin{array}{l}\text { Pearson } \\
\text { correlation } \\
\text { Sig }\end{array}$ & 3.6163 & .57393 & $\begin{array}{c}.412 * * \\
.000\end{array}$ & $\begin{array}{c}.500 * * \\
.000\end{array}$ & 1 \\
\hline
\end{tabular}

**. Correlation is significant at the 0.01 level (2-tailed).

Table 3 depicts correlational impact of variables, as T\&D correlates EP at $72 \%$ indicating strong positive linkage and significant relationship, and JS at $41.2 \%$ showing satisfactory positive and significant association. Also, EP correlates JS at 50\% showing good positive and significant relationship. 
Table 4. Regression

4.1) Impact of Training and Development on Job Satisfaction

\begin{tabular}{ccccc} 
Variable & $\boldsymbol{\beta}$ & $\mathbf{R}^{2}$ & $\boldsymbol{\Delta} \mathbf{R}^{2}$ & Sig. \\
\hline TD & .412 & .170 & .162 & .000 \\
\hline
\end{tabular}

$\mathrm{DV}=\mathrm{JS}$

$\mathrm{R}=.412, \mathrm{~F}=21.052$

Table 4.1 shows regression analysis, as illustrating 1 unit change in T\&D will bring $41.2 \%$ units change in JS, demonstrating satisfactory positive relationship ( $\mathrm{R}=41.2 \%, \mathrm{R}^{2}=17 \%$, $\Delta \mathrm{R}^{2}=16 \%$ ), and can be generalized on population $(\mathrm{F}=21.052 \%)$.

4.2) Impact of Training and Development on Employee Performance

\begin{tabular}{ccccc} 
Variable & $\boldsymbol{\beta}$ & $\mathbf{R}^{2}$ & $\Delta \mathbf{R}^{\mathbf{2}}$ & Sig. \\
\hline TD & .608 & .516 & .511 & .000 \\
\hline
\end{tabular}

$\mathrm{DV}=\mathrm{EP}$

$\mathrm{R}=.718, \mathrm{~F}=109.611$

Table 4.2 shows regression analysis illustrating 1 unit change in T\&D will bring $61 \%$ units change in EP, demonstrating positive and significant relationship ( $\mathrm{R}=72 \% \%, \mathrm{R}^{2}=52 \%$, $\left.\Delta \mathrm{R}^{2}=51 \%\right)$ and can be generalized on population $(\mathrm{F}=11 \%)$.

4.3) Impact of Job Satisfaction on Employee Performance

\begin{tabular}{ccccc}
\hline Variable & $\boldsymbol{\beta}$ & $\mathbf{R}^{2}$ & $\boldsymbol{\Delta} \mathbf{R}^{\mathbf{2}}$ & $\boldsymbol{S}$ Sig. \\
\hline JS & .424 & .250 & .243 & .000 \\
\hline
\end{tabular}

$\mathrm{DV}=\mathrm{EP}$

$\mathrm{R}=.500, \mathrm{~F}=34.309$

Table 4.3 shows regression analysis illustrating 1 unit change in JS will bring $42.4 \%$ units change in EP, demonstrating positive and significant relationship $\left(\mathrm{R}=50 \%, \mathrm{R}^{2}=25 \%\right.$, $\left.\Delta \mathrm{R}^{2}=24.3 \%\right)$, and can be generalized on population $(\mathrm{F}=34.309 \%)$. 
Table 5. Mediation: Impact of T\&D on Employee Performance mediated by Job Satisfaction

\begin{tabular}{ccccc}
\hline Variable & $\boldsymbol{\beta}$ & $\mathbf{R}^{2}$ & $\Delta \mathbf{R}^{\mathbf{2}}$ & Sig. \\
\hline TD & .522 & & & .000 \\
JS & .208 & .566 & .557 & \\
\hline
\end{tabular}

$\mathrm{DV}=\mathrm{EP}$

$\mathrm{R}=.752, \mathrm{~F}=66.433$

Table 5 illustrates mediation analysis of variables, as 1 unit change in T\&D will bring $52.2 \%$ units change in EP and on the other hand, 1 unit change in JS will cause $21 \%$ units change in EP, both indicating positive and significant relationship. There is an indication of partial mediation of job satisfaction between T\&D on EP.

\section{Managerial Implications}

With the help of the results, it is very easy to identify a number of implications for managers in order to improve employee performance. Training and development is a strong driver leading towards employee performance. So the managers should make strategies to carry out or conduct efficient and effective training programs which will develop the skills of employees at every level. For this purpose it is necessary to figure out for managers that which employees need training due to which employees are not performing well because of any hurdle in their way. Managers need to conduct regular meetings with their employees and listen to their problems and not only listen but also provide solutions to their problems. When the employees will feel satisfaction that managers are paying attention to their problems and they are available to employees, as a result employees will be loyal and job satisfaction level will be high. Managers should also frequently ask employees about their obstacles in performing well or up to the task. Sometimes employees are unable to perform the tasks given to them by managers because they are unable to coup with the changes that are going on in the organization like that of technological change. During research it was found that great number of respondents agreed to the fact that older employees don't welcome changes in their way of working like they still use the paper and pen for any documentation instead of using computers or laptops. So in such case managers should convince the employees that there is no shame in going under T\&D programs to learn something new which will save their and organization's time.

Job satisfaction will not be achieved until and unless the employees are given importance. Importance can be given to them in various ways $T \& D$ is one of the ways by which employee feels that the organization is taking care of the problems which were stopping them to enhance their performance. Employee performance is highly influenced by training and development as the results suggested. So why delay when everyone knows that training will 
be beneficial both for employees and management. Employees need to be trained in order to increase their skills and skilled workers in return give back their best to organization by completing the tasks and goals given to them. In the end managers should be flexible and cooperative with their employees and have a lot of patience for the employees who, due to any reason are not performing well or not taking part in T\&D programs. Awareness about such programs should be given to them in a good way so that they also can contribute to success of organization.

\section{Conclusion}

The results of this research strongly supported the relationship of training and development of employees with the employee performance. This research was not on large scale, the researchers can carry this research on large scale to emphasize strongly on benefits of training and development. The results show that performance is increased with skills improving by $\mathrm{T} \& \mathrm{D}$ programs and also satisfaction level is high among employees if they are given proper training. The gap between knowledge and skills possessed by the employees and the skills required to perform effectively and efficiently, should be narrowed down by creating awareness among employees as well as among managers regarding benefits of training and development. This awareness can be created by researchers by emphasizing on benefits of training and development, and more and more papers are needed to be written on these variables, so that managers can be encouraged that it's a win -win situation if they will arrange $\mathrm{T} \& \mathrm{D}$ programs.

\section{Limitations and Future work}

This research was conducted on telecom sector of Abbottabad, Haripur and Mansehra. Researchers can conduct same research in any other sector like that of education sector or hospital sector or some other industry like hotel industry or medicine industry. This research can also be conducted in any other cities, provinces or any other country. Other sampling methods can also be used.

\section{References}

Abbas, Q., \& Yaqoob, S. (2009). Effect of leadership development on employee performance in Pakistan. Pakistan Economic and Social Review, 47(2), 269-292.

Abdulla, J., Djebarni, R., \& Mellahi, K. (2011). Determinants of job satisfaction in the UAE: A case study of the Dubai police. Personnel review, 40(1), 126-146. http://www.dx.doi.org/10.1108/00483481111095555

Achieng'Odembo, s. (2013). Job Satisfaction And Employee Performance Within The Telecommunication Industry In Kenya: A Case Of Airtel Kenya Limited. Kenyatta University.

Ahmad, I., \& ud Din, S. (2009). Evaluating Training and Development. Gomal Journal of Medical Sciences, 7(2).

Ahmad, K. Z., \& Bakar, R. A. (2003). The association between training and organizational 
commitment among white-collar workers in Malaysia. International Journal of Training and Development, 7, 166-185. http://www.dx.doi.org/10.1111/1468-2419.00179

Aktar, S., Sachu, M. K., \& Ali, M. E. (2012). The impact of rewards on employee performance in commercial banks of Bangladesh: an empirical study. IOSR Journal of Business and Management, 6(2), 9-15.

Anjum, S. (2014). Effect of Manager's Social Skills on Employee's Job Satisfaction. Journal of Strategy and Performance Management, 2(1), 6-16.

Arnoff, J. (1971). Achievement Motivations Training and Executives advancement. Journal of Applied Science New York, 7(1). http://www.dx.doi.org/10.1177/002188637100700207

Asim, A. I., Waqas, M., \& Cheema, L. J. (2012). Mediating Character of Readiness to Change Between Training \& Development And Employees Performance. Arabian Journal of Business and Management Review (Oman Chapter), 2(1), 1.

Bataineh, K. A. A. (2014). Impacts of Employee Training on the Performance of Commercial Banks in Jordan. European Journal of Business and Management, 6(27), 192-196.

$\begin{array}{llll}\text { Case study } & \text { telecommunication } & \text { Pakistan. } & \text { from }\end{array}$ http://www.cuts-citee.org/tdp/pdf/case_study-telecommunication-pakistan.pdf

Cheramie, R. A., Sturman, M. C., \& Walsh, K. (2007). Executive career management: Switching organizations and the boundaryless career. Journal of Vocational Behavior, 71(3), 359-374. http://www.dx.doi.org/10.1016/j.jvb.2007.09.002

Chidambaram, V., \& Ramachandran, A. (2012). A study on efficacy of employee training: Review of literature. Business: Theory and Practice/Verslas: Teorija ir Praktika, 13(3), 275-282. http://www.dx.doi.org/10.3846/btp.2012.29

Cook, J. D., \& Heptworth, S. J. (1981). The experience of work: A compendium and review of 249 measures and their use: Academic Press London.

Dayal, I. (1970). Conceptual framework for determining training needs in an organization.

Elangovan, A., \& Karakowsky, L. (1999). The role of trainee and environmental factors in transfer of training: An exploratory framework. Leadership \& Organization Development Journal, 20(5), 268-276. http://www.dx.doi.org/10.1108/01437739910287180

Ellickson, M. C., \& Logsdon, K. (2002). Determinants of job satisfaction of municipal government employees. Public Personnel Management, 31(3), 343-358. http://www.dx.doi.org/10.1177/009102600203100307

Elnaga, A., \& Imran, A. (2013). The effect of training on employee performance. European Journal of Business and Management, 5(4), 137-147.

Gamage, P., \& Imbulana, L. (2013). Training development and performance of employee: Evidence from Shrilanka telecom. International Jour. of Marketing, Financial Services and 
Management Research, 2(9), 12-24.

Gibson, J. W. (1990). The Supervisory Challenge: Principles and Practices: Merrill Publishing Company.

Guest, D. E. (1997). Human resource management and performance: a review and research agenda. International journal of human resource management, 8(3), 263-276. http://www.dx.doi.org/10.1080/095851997341630

Gupta, I. (2014). IMPACT OF JOB SATIFACTION ON EMPLOYEE'S PERFORMANCE. scholarly research journal for interdisciplinary studies, 2(15), 2307- 2317.

Hafeez, U., \& Akbar, W. (2015). "Impact of Training on Employees Performance” (Evidence from Pharmaceutical Companies in Karachi, Pakistan). Business Management and Strategy, 6(1), 49-64. http://www.dx.doi.org/10.5296/bms.v6i1.7804

Hameed, A., \& Waheed, A. (2011). Employee development and its affect on employee performance a conceptual framework. International journal of business and social science, 2(13), 224-229.

Hunter, J. E., \& Hunter, R. F. (1984). Validity and utility of alternative predictors of job $\begin{array}{llll}\text { performance. } & \text { Psychological bulletin, } & 96(1), & 72 .\end{array}$ http://www.dx.doi.org/10.1037/0033-2909.96.1.72

Imran, M., \& Tanveer, A. (2015). IMPACT OF TRAINING \& DEVELOPMENT ON EMPLOYEES'PERFORMANCE IN BANKS OF PAKISTAN. European Journal of Training and Development Studies, 3(1).

Imran, M., Maqbool, N., \& Shafique, H. (2014). Impact of Technological Advancement on Employee Performance in Banking Sector. International Journal of Human Resource Studies, 4(1), 57-70.

Imtiaz, S. Y., Khan, M. A., \& Shakir, M. (2015). Telecom sector of Pakistan: Potential, challenges and business opportunities. Telematics and Informatics, 32(2), 254-258. http://www.dx.doi.org/10.1016/j.tele.2014.09.002

Iun, J., \& Huang, X. (2007). How to motivate your older employees to excel? The impact of commitment on older employees' performance in the hospitality industry. International $\begin{array}{llll}\text { Journal of Hospitality } & \text { Management, } & \text { 26(4), }\end{array}$ http://www.dx.doi.org/10.1016/j.ijhm.2006.08.002

Javaid, K., Ahmad, N., \& Iqbal, N. (2014). Impact of Training on Employee Performance in the context of Telecommunication sector of DG Khan,(Pakistan). International Letters of $\begin{array}{llll}\text { Social and Humanistic } & \text { 60-73. }\end{array}$ http://www.dx.doi.org/10.18052/www.scipress.com/ILSHS.17.60

Jehanzeb, K., \& Bashir, N. A. (2013). Training and development program and its benefits to employee and organization: A conceptual study. European Journal of Business and 
Management, 5(2), 243-252.

Kadiresan, V., Selamat, M. H., Selladurai, S., SPR, C. R., \& Mohamed, R. K. M. H. (2015). Performance Appraisal and Training and Development of Human Resource Management Practices (HRM) on Organizational Commitment and Turnover Intention. Asian Social Science, 11(24), 162.

Kahya, E. (2009). The effects of job performance on effectiveness. International Journal of Industrial Ergonomics, 39(1), 96-104. http://www.dx.doi.org/10.1016/j.ergon.2008.06.006

Kavita, G., Simran, K., Pramod, G., Lalit, J., \& K., S. S. (2012). Impact of Job Satisfaction on Employee Performance, a Challenge for HR Managers in Changing Environment. International Journal of Scientific Research and Reviews, 1(3), 88-95.

Kennedy, J. (2009). The Impact of Training and Development on Job Performance. Service of Ghana) BY JOSEPH KENNEDY A thesis submitted to the Institute of Distance Learning, Kwame Nkrumah University of Science and Technology.

Khan, K., \& Imtiaz, A. Occupational Stressors and Employee Performance in Service Sector of Lahore, Pakistan. Journal of Research (Humanities).

Kulkarni, P. P. (2013). A Literature Review on Training \& Development and Quality of Work Life. Researchers World, 4(2), 136.

Kum, F. D., \& Cowden, R. (2014). The Impact Of Training And Development On Employee Performance: A Case Study Of Escon Consulting. Singaporean Journal Of Business Economics, ANd management studies, 3(3).

Locke, E. A. (1976). The nature and causes of job satisfaction. Handbook of industrial and organizational psychology, 1, 1297-1343.

Mansour, M. (2013). Evaluation of Training in Organizations: An Empirical Investigation from a Developing Country. International journal of education and research, 1(6), 1-12.

Masood, A., Aslam, R., \& Rizwan, M. (2014). Factors Affecting Employee Satisfaction of the Public and Private Sector Organizations of Pakistan. International Journal of Human Resource Studies, 4(2), 97-121.

Masood, T. (2010). Impact of Human Resource Management (HRM) Practices on Organizational Performance: A mediating role of employee performance. MOHAMMAD ALI JINNAH UNIVERSITY ISLAMABAD.

McConnell, C. R. (2004). Managing employee performance. The health care manager, 23(3), 273-283.

Mudor, H., \& Tooksoon, P. (2011). Conceptual framework on the relationship between human resource management practices, job satisfaction, and turnover. Journal of Economic and Behaviors Studies, 2(2), 41-49. 
Naris, N. S., \& Ukpere, I. W. (2009). The effectiveness of an HR code: Staff development and training at the Polytechnic of Namibia. Afr. J. Bus. Manage, 3(12), 879-889.

Niazi, B. R. A. S. (2011). Training and development strategy and its role in organizational performance. Journal of public Administration and Governance, 1(2), 42-57. http://www.dx.doi.org/10.5296/jpaq.v1i2.862

Osunde, D. C. (2015). Privatization of Public Enterprises In Nigeria: Impact On Employees' Performance And Managerial Implications. International Journal Of Research -Grant Haalayah A Knowledge Repository, 3(3).

$\begin{array}{llll}\text { Pakistan } & \text { economic } & \text { (2014-15). } & \text { from }\end{array}$ http://www.finance.gov.pk/survey/chapters_15/Highlights.pdf

Pushpakumari, M. (2008). The impact of job satisfaction on job performance: An empirical analysis. City Forum, 9(1), 89-105.

Rothbard, N. P., Phillips, K. W., \& Dumas, T. L. (2005). Managing multiple roles: Work-family policies and individuals' desires for segmentation. Organization Science, 16(3), 243-258. http://www.dx.doi.org/10.1287/orsc.1050.0124

Saif, D. M. I., Malik, M. I., \& Awan, M. Z. (2011). Employee Work Satisfaction and Work Life Balance: A Pakistani Perspective. Interdisciplinary Journal Of Contemporary Research In Business, 3(5).

Shaikh, M. A., Bhutto, N. A., \& Maitlo, Q. (2012). Facets of job satisfaction and its association with performance. International journal of business and social science, 3(7), 322-326.

Shanawany, S. (2001). Personnel management and human relations: ARE.

Spector, P. E. (1997). Job satisfaction: Application, assessment, causes, and consequences (Vol. 3): Sage.

Stavrou, E., Brewster, C., \& Charalambous, C. (2004). Human resource management as a competitive tool in Europe.

Sultana, A., Irum, S., Ahmed, K., \& Mehmood, N. (2012). Impact Of Training On Employee Performance: A Study Of Telecommunication Sector In Pakistan. Interdisciplinary Journal Of Contemporary Research In Business, 4(6).

Sušanj, Z., \& Jakopec, A. (2012). Fairness perceptions and job satisfaction as mediators of the relationship between leadership style and organizational commitment. Psihologijske teme, $21(3), 509-526$.

Testa, M. R. (1999). Satisfaction with organizational vision, job satisfaction and service efforts: an empirical investigation. Leadership \& Organization Development Journal, 20(3), 154-161. http://www.dx.doi.org/10.1108/01437739910268424 


\section{Macrothink}

Business Management and Strategy ISSN 2157-6068 2016, Vol. 7, No. 1

Uddin, M. J., Luva, R. H., \& Hossain, S. M. M. (2012). Impact of organizational culture on employee performance and productivity: A case study of telecommunication sector in Bangladesh. International Journal of Business and Management, 8(2), 63.

Velnampy, T. (2008). Job attitude and employees performance of public sector organizations in Jaffna district, Sri Lanka. GITAM Journal of Management, 6(2), 66-73.

Vroom, V. H. (1964). Work and motivation. New York: John Willey \& Sons: Inc.

\section{Copyright Disclaimer}

Copyright for this article is retained by the author(s), with first publication rights granted to the journal.

This is an open-access article distributed under the terms and conditions of the Creative Commons Attribution license (http://creativecommons.org/licenses/by/3.0/). 